\title{
SINGLE FOLDS AT THE MARGINS OF DRY-BASED GLACIERS AS INDICATORS OF A GLACIAL ADVANCE
}

\author{
by
}

T.J.H. Chinn

(New Zealand Geological Survey, Christchurch, New Zealand)

\begin{abstract}
Single folds which enclose the marginal "inner moraines" of the dry-based Jeremy Sykes and Alberich Glaciers, Dry Valleys area, Antarctica, are deduced to have formed during an advance of the margins of these glaciers where the thin, stiff marginal ice has obstructed glacier flow and expansion.

It is suggested that the occurrence of this type of fold can be an indicator of an advance in many fully dry-based glaciers. On Alberich Glacier, the fold and associated margin forms suggest that a sequence of margin forms evolves when a small cirque glacier expands outward from a sloping ramp front to a tongue terminating in a calving ice
\end{abstract} cliff.

\section{INTRODUCTION}

In simple glaciers, foliation derived from sedimentary stratigraphy of the nevvé is carried to the lower margins where it appears as bands of discoloured ice. The beds normally assume a shallow synclinal structure with dips sloping inward towards the glacier centre. This basic structural pattern is displayed at both the ice-ramp and ice-cliff margins of the dry-based Dry Valleys glaciers. A discoloured basal ice bed which accommodates the bulk of the flow deformation is normally close to $1 \mathrm{~m}$ in thickness across the glacier sole, and has been termed "amber ice" (Holdsworth, unpublished). At the lower margins and terminus of the glacier, this basal bed rises to over-ride a surrounding snow and ice apron, and appears at the surface as a single line of debris. This englacial material accumulated by ablation lies between structured glacier ice of the ablation zone and the surrounding snow and ice apron. These marginal supraglacial lines of moraine have been variously named "inner moraines" (Weertman, 1961), "shear moraines" (Bishop, 1957), and to avoid generic implications "ice-cored moraines" by Souchez (1971). Antarctic examples have been described by Hollin and Cameron (1961) and Souchez (1967) but they are also common in Arctic regions and have been studied on Baffin Island (Hooke, 1973a, b) and near Thule in north Greenland (Hooke, 1970).

During a study of Meserve Glacier, Holdsworth (1969) recognized five different flow zones in the ice tongue, with four zones in the immediate vicinity of the ice cliff: a "rigid" outer zone, a "semi-rigid" zone, a "semi-plastic" zone, and an interior basal "plastic" zone. The zones essentially subdivide the gradational changes in the rheological properties of ice which occur with increasing thickness. One which he regarded as particularly important was the semi-rigid zone, a brittle layer about $20 \mathrm{~m}$ in thickness, covering the glacier surface and containing the ice cliff.

Ice becomes more plastic with depth and thicker ice of a glacier trunk will flow more easily than thinner ice at the margins. Where a glacier thins to about $20 \mathrm{~m}$ near the margin, the more easily deformed plastic basal layers are excluded as the semi-rigid crust grounds to become a stiff obstruction to flow and, depending on the rate of movement, forms an ice cliff, or a gibbous or a ramped glacier terminus. The ice cliffs in the Dry Valleys area are uniformly close to $20 \mathrm{~m}$ in height, a characteristic of dry-based glaciers. The lower the gradient of the glacier front, the greater the width of the rigid zone which is grounded and the more impeded the ice flow.

Small, dry-based glaciers of simple form, whose balances are in equilibrium, should show undeformed marginal and surface foliation delineating a synclinal structure. The margins may take any of the transitional forms between an actively calving ice cliff and a low-angled ramp. Any deviation from this uniform foliation of the basic synclinal structure indicates that some form of abnormal deformation may have occurred.

\section{JEREMY SYKES AND ALBERICH GLACIERS}

The Dry Valleys area of Victoria Land, Antarctica, located between $77^{\circ} 15^{\prime}$ and $78^{\circ} \mathrm{S}$, is a cold desert covering about $2500 \mathrm{~km}^{2}$ where mean annual valley-floor temperatures are around $-20^{\circ} \mathrm{C}$ (Thompson, 1973). The area comprises three main valleys (Fig. 1) separated by east-west-trending mountain ranges reaching $2400 \mathrm{~m}$ elevation. The ranges support local "alpine-type" glaciers, all of which are dry-based polar glaciers, strikingly devoid of surface moraine, and which terminate in a variety of margin forms.

Measured glacier mass-balance changes in Wright Valley are very small and close to equilibrium (Bull and Carnein, 1970; Chinn, 1980), while measurements of the frontal positions of ice-cliffed glaciers have shown that some are advancing whereas others are receding with fluctuations in the order of $1 \mathrm{~m} \mathrm{a}^{-1}$ (McSaveney, 1974; Chinn, [1985]). Mean elevations of the glaciers increase inland towards the west.

Jeremy Sykes and Alberich Glaciers are adjacent glaciers located at $77^{\circ} 36^{\prime} \mathrm{S}, 160^{\circ} 33^{\prime} \mathrm{E}$ on the Asgard Range above Wright Valley (Fig. 1). Both glaciers have been studied for mass balance over a 6 year period (Chinn, 1980, 1981). Jeremy Sykes Glacier comprises two coalescing valley glaciers with a total area of $9.9 \mathrm{~km}^{2}$ and a total length of $7.6 \mathrm{~km}$ (Fig. 2). Alberich Glacier is a small simple cirque glacier with an area of $1.36 \mathrm{~km}^{2}$ and a length of $1.5 \mathrm{~km}$.

On each of these two glaciers, a semi-circular structure with its axis normal to the ice-flow direction was found in the foliated ice of the glacier margin. In both cases, the linear supraglacial or inner moraine may be followed up-glacier from the glacier front to a position where it terminates within the semi-circular structure. These semicircular features were studied during the austral summer of $1982-83$ and are the subject of this paper.

\section{FIELD OBSERVATIONS}

Both of the structures studied occur on uniformly sloping "ramp" margins with a surface gradient of about 10 . Orientations of structural folia were measured with a compass clinometer at sections chipped into the ice. Sample sites were positioned for mapping from triangulation by tape measure. 


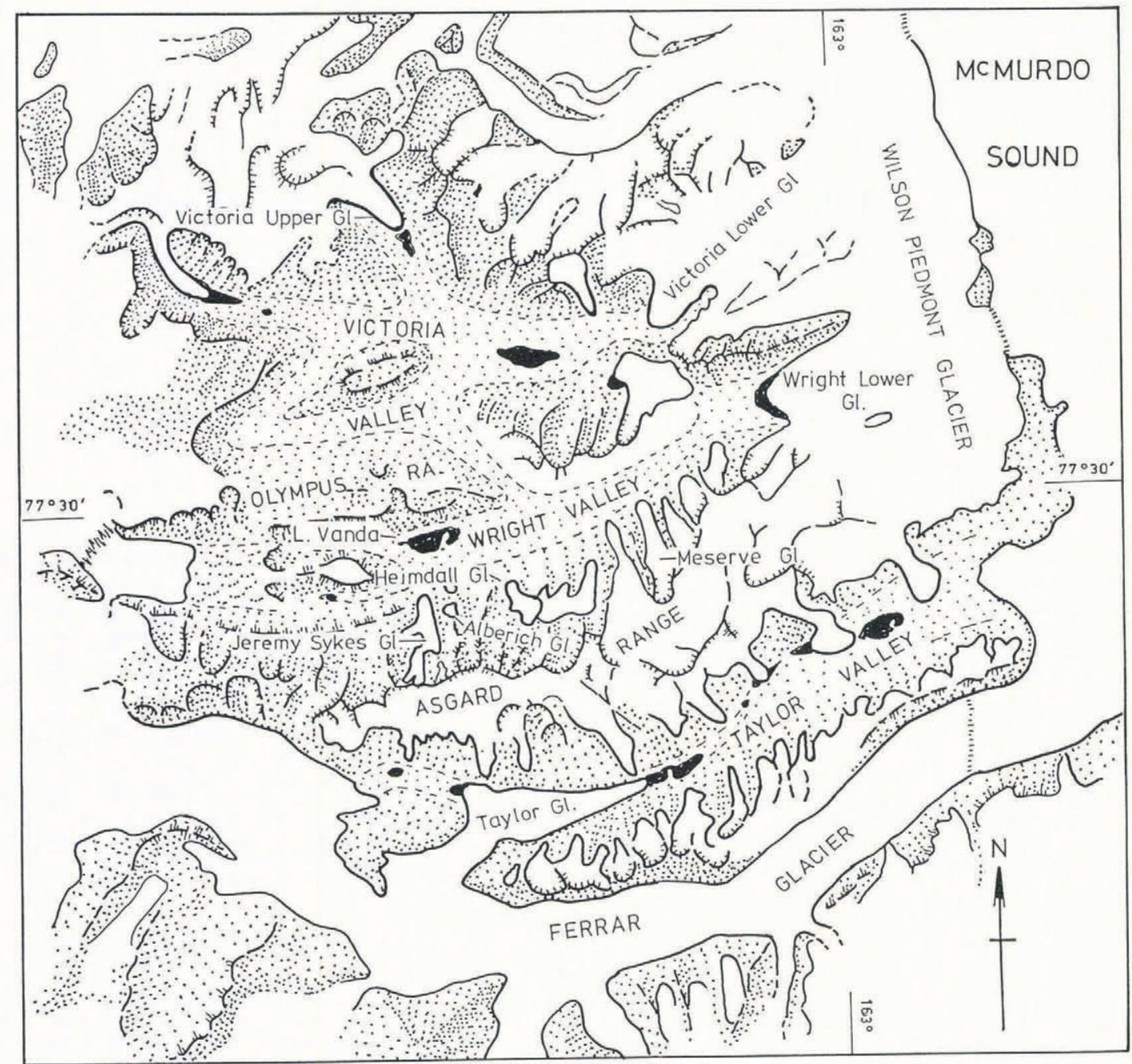

DRY VALLEYS REGION, ANTARCTICA

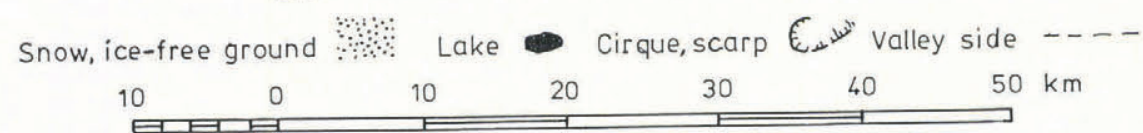

Fig. 1. Location of Jeremy Sykes and Alberich Glaciers, Dry Valleys area, Victoria Land, Antarctica.

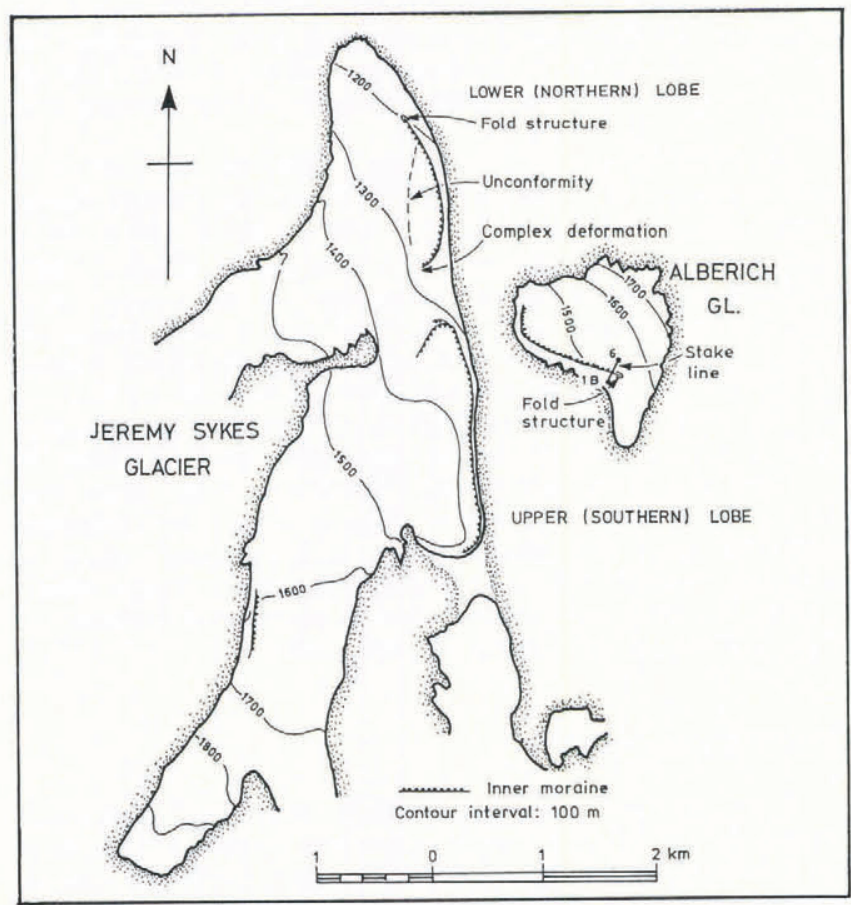

Fig. 2. Jeremy Sykes and Alberich Glaciers, showing locations of the folds and other features.
On the sloping margins of glaciers in this area, the surface features normally encountered in a down-glacier sequence shown in Figure 3 are: debris-free banded ice on a convex slope; a single band of clean white ice; discoloured debris-rich amber ice, overlain by the inner moraine; a concave snow and refrozen melt-water apron grading out to the ground surface.

The semi-circular feature studied on Alberich Glacier surrounds the upper end of the inner moraine (Figs 2 and 4) where the glacier terminates in an ice ramp with a gentle $8^{\circ}$ convex slope changing to a $4^{\circ}$ concave slope below the moraine. Foliae on the glacier surface parallel the inner moraine to where it terminates. Here, the foliae curl in a semi-circle around the end of the moraine (Fig. 5) to parallel again the glacier margin but in a position below the inner moraine. These foliae are exposed for only a short distance before being obscured by snow and superimposed ice. Bands of foliation lying above the moraine are repeated, inverted, below the moraine in the position normally occupied by the unsystematic structure of the snow apron.

An almost identical structure was found on the lower lobe of Jeremy Sykes Glacier (Figs 2 and 6). Again, the structure encircled the end of the inner moraine at a ramp margin sloping at $10^{\circ}$, and the beds of foliae above the moraine were repeated, inverted, below the moraine.

Both structures were single folds with steep plunges away from the glacier centres (Figs 7 and 8 ).

Both glaciers were investigated further for additional unusual structures. Alberich Glacier contained no other 


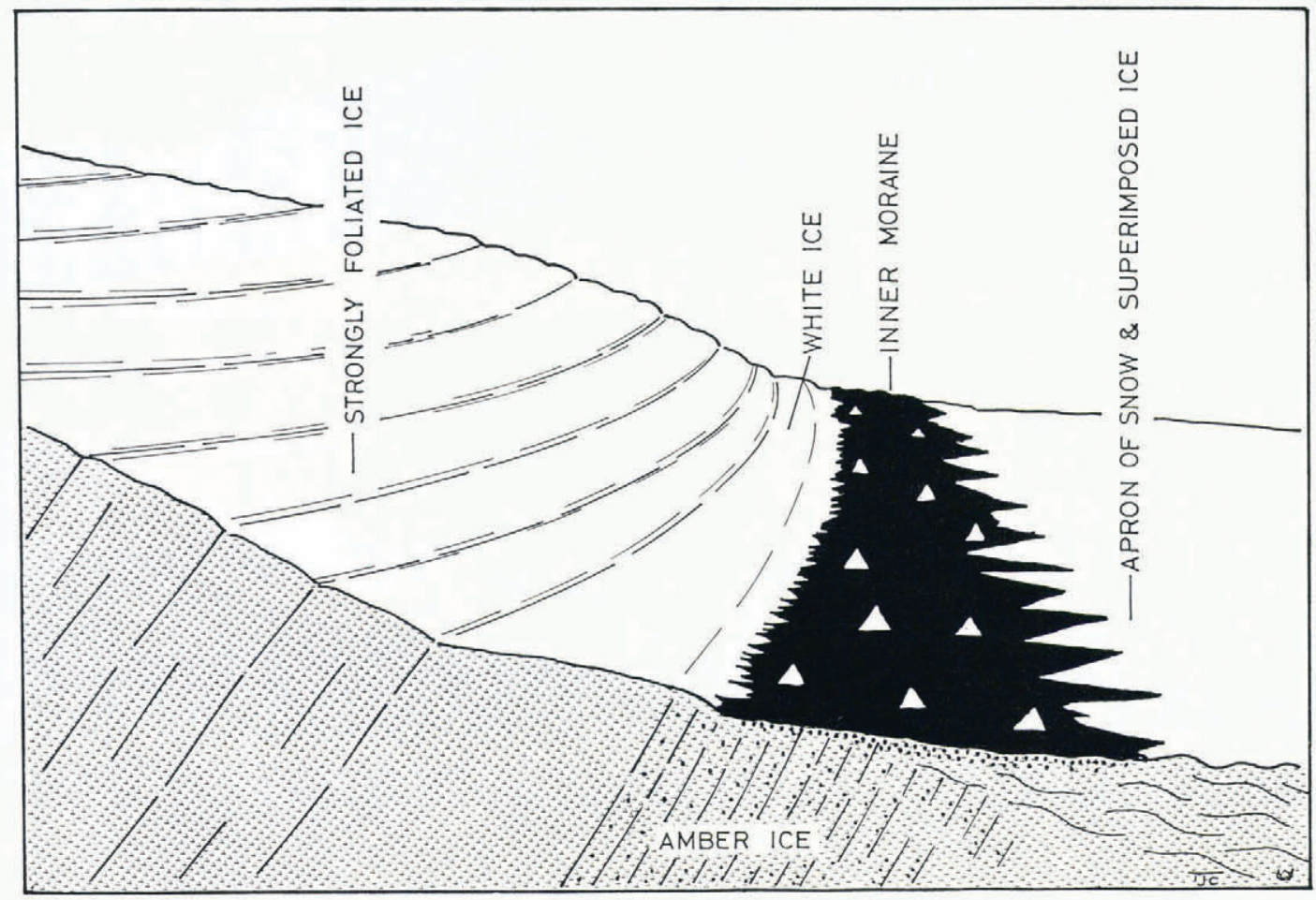

Fig. 3. Common sequence of features at the sloping margins of glaciers of the Dry Valleys area.

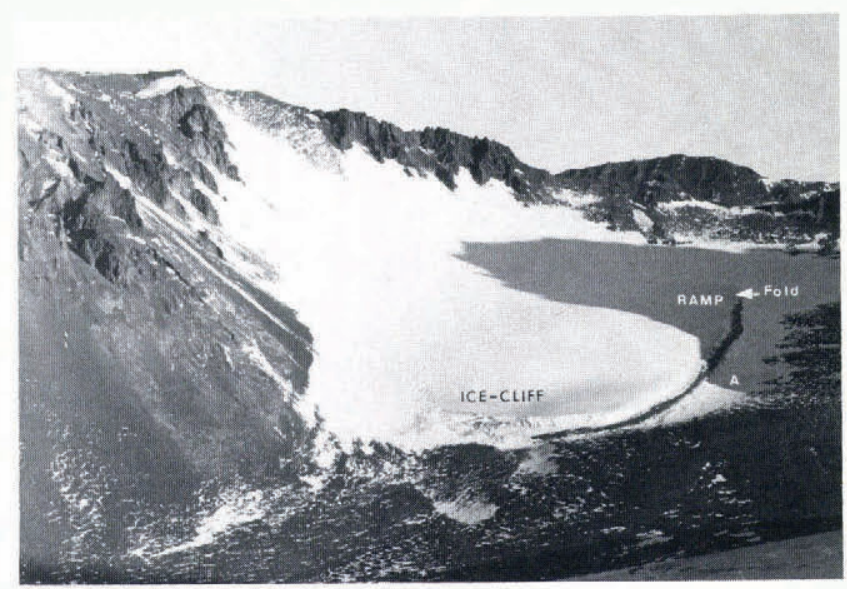

Fig. 4. Alberich Glacier, showing location of fold structure, inner moraine, snow apron A, and margin shape grading from a ramped margin through a gibbous margin to an ice cliff. unusual features. The inner moraine continued down-glacier uninterrupted from the fold structure, beneath a progressively steepening margin, to its position beneath an active calving ice cliff (Fig. 4).

Both lobes of Jeremy Sykes Glacier, however, contained a number of additional structures indicative of deformation (Fig. 6). Across the frontal margin of the lower lobe, the inner moraine stretched southward from the semi-circular structure, around the ice dome of the lower lobe to terminate in an area of multiple folds containing a second partly obscured semi-circular structure (Fig. 9). Midway along the front of the lobe, the apparently uniform foliae of the domed margin included an area of very tight isoclinal folds (Fig. 6). A discoloured band across the entire lobe (Fig. 6) appeared to be an unconformity of sedimentary origin formed during a past lowering of the equilibrium line.

Ablation measurements have been made on both glaciers over a 6 year period of mass-balance studies (Chinn, 1980). Mean annual surface changes in millimetres of ice are given in Table I for a section across the margin of Alberich Glacier within $100 \mathrm{~m}$ of the structure studied, and for the area at the semi-circular structure on Jeremy Sykes

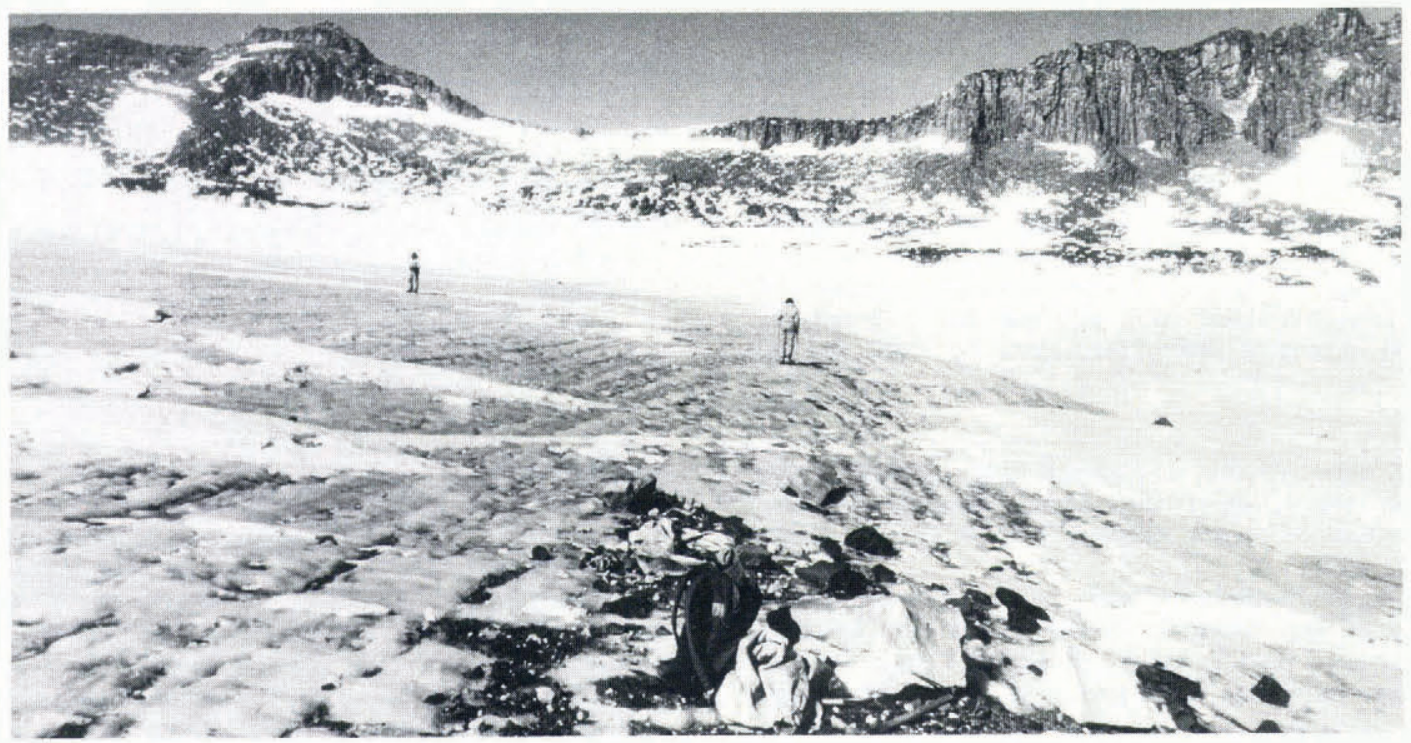

Fig. 5. The semi-circular structure on Alberich Glacier. 


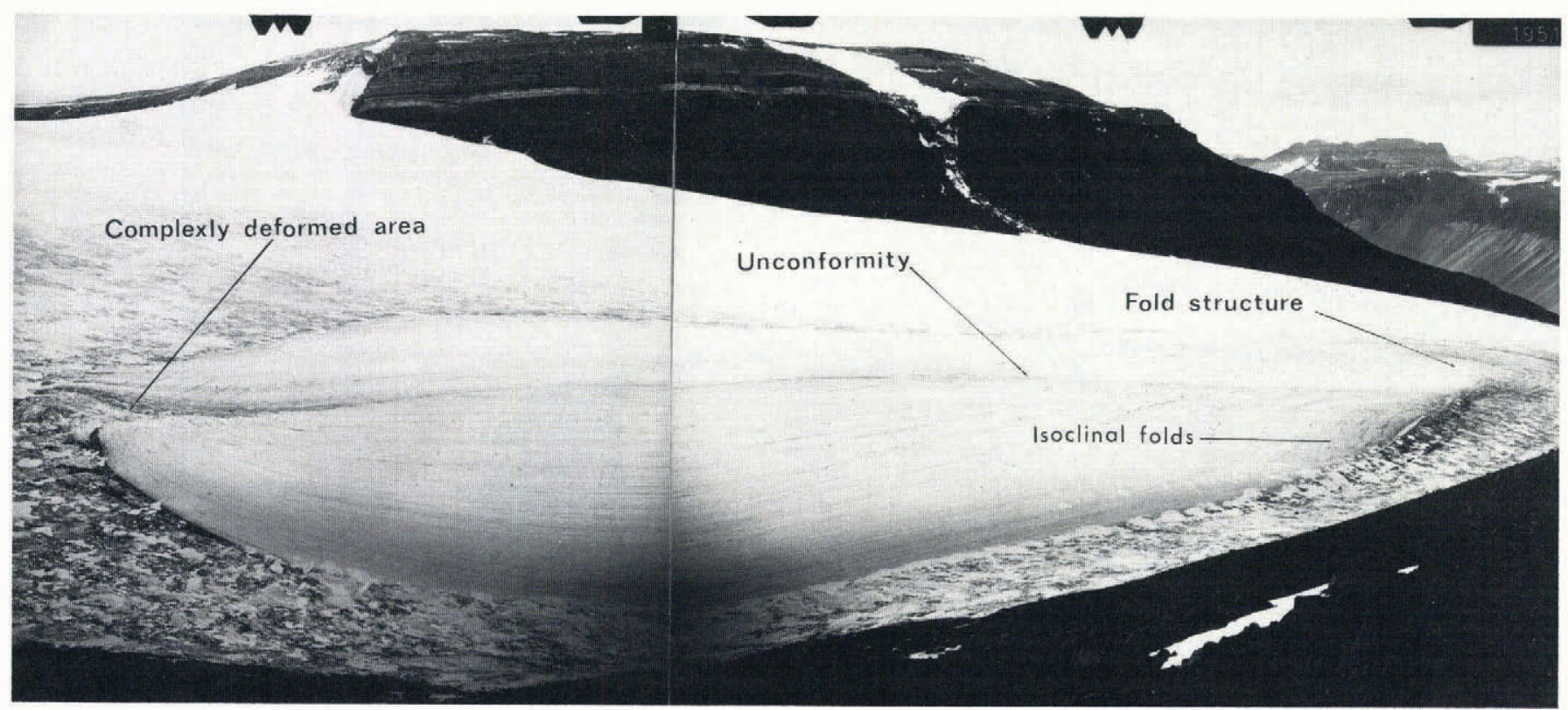

Fig. 6. The northern (lower) lobe of Jeremy Sykes Glacier, showing areas of deformation and anomalous structures. (Phototheodolite photograph by S. Myagkov, February 1971.)

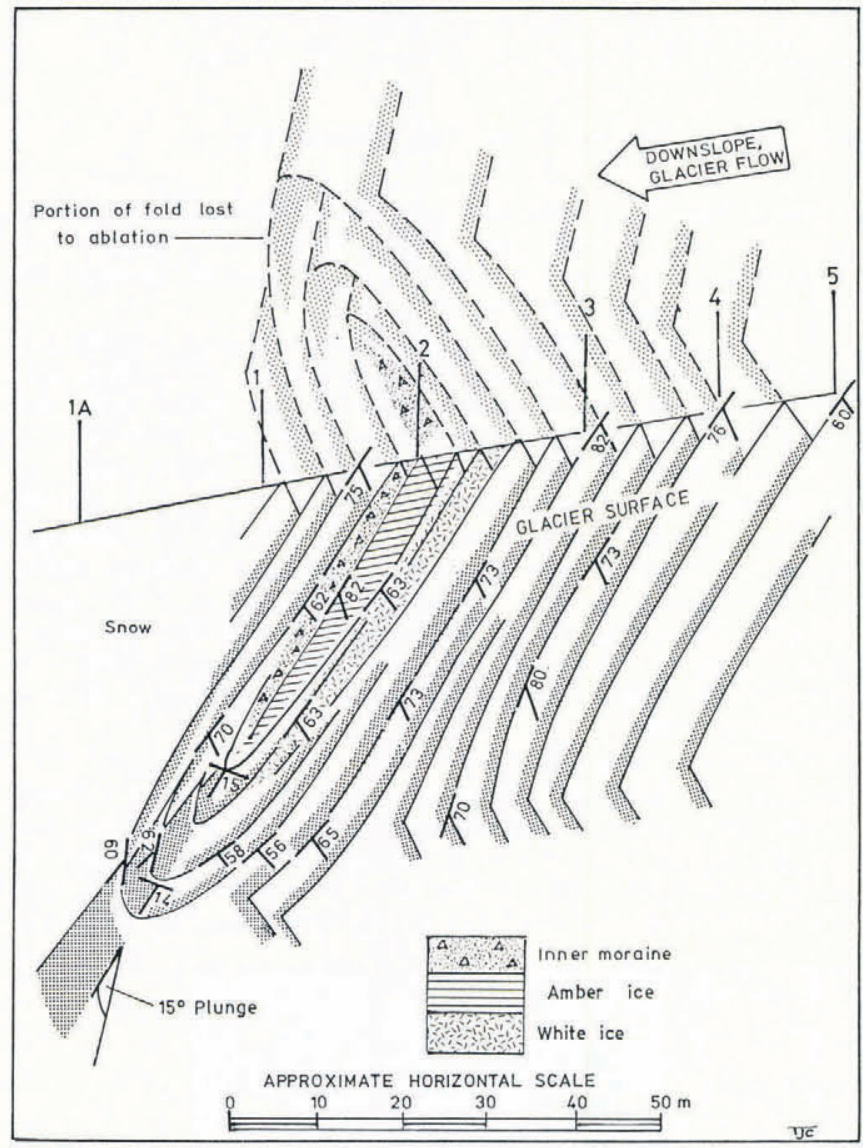

Fig. 7. Oblique sketch showing mapped and interpretative structure of the semi-circular structure on Alberich Glacier. Verticals $1 \mathrm{~A}$ to 5 give approximately locations of the stake line measured for ablation and movement. Dashed lines represent interpreted part of fold lost to ablation.

Glacier. Being close to the equilibrum line, ablation rates are lower than those nearer the glacier termini, and are highest on the steeper, more exposed site on Jeremy Sykes Glacier (Chinn, 1987).

Surveys of ice movement, made at the time of massbalance studies at the structure in the margin of Alberich Glacier, show typical low rates of movement (Table I) with compressive flow extending into the snow apron. The inner moraine is moving outwards horizontally at about $50 \mathrm{~mm} \mathrm{a}^{-1}$.

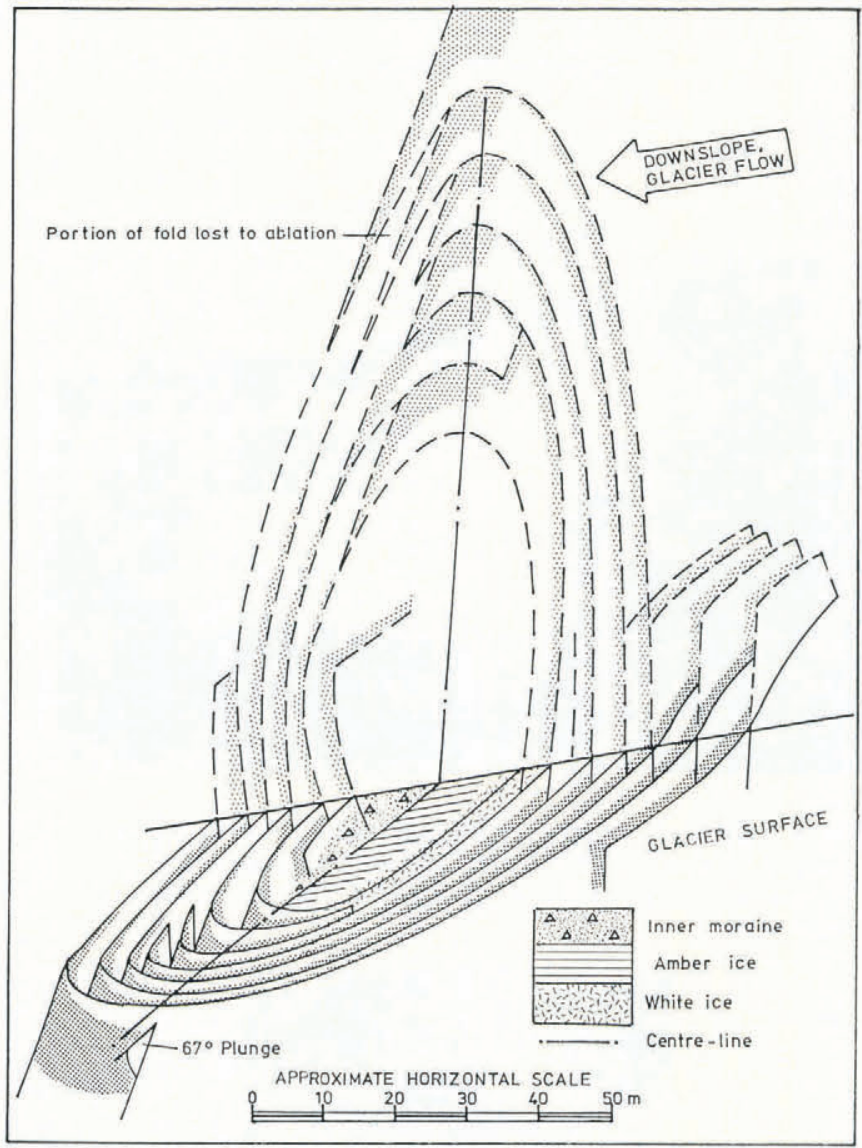

Fig. 8. Oblique sketch showing mapped and interpretative structure (dashed lines) of the fold on Jeremy Sykes Glacier.

\section{DISCUSSION}

The two single-fold structures occur in similar positions on the glaciers, lying at the ends of the inner moraines, in the transition from a névé margin to a structured ice margin. Folds in glaciers can be formed by several processes. In a viscous medium having a layered rheologic structure, buckling may occur under longitudinal compression (Johnson, 1977), while folds in glacial ice commonly result from flow that is non-steady with time 


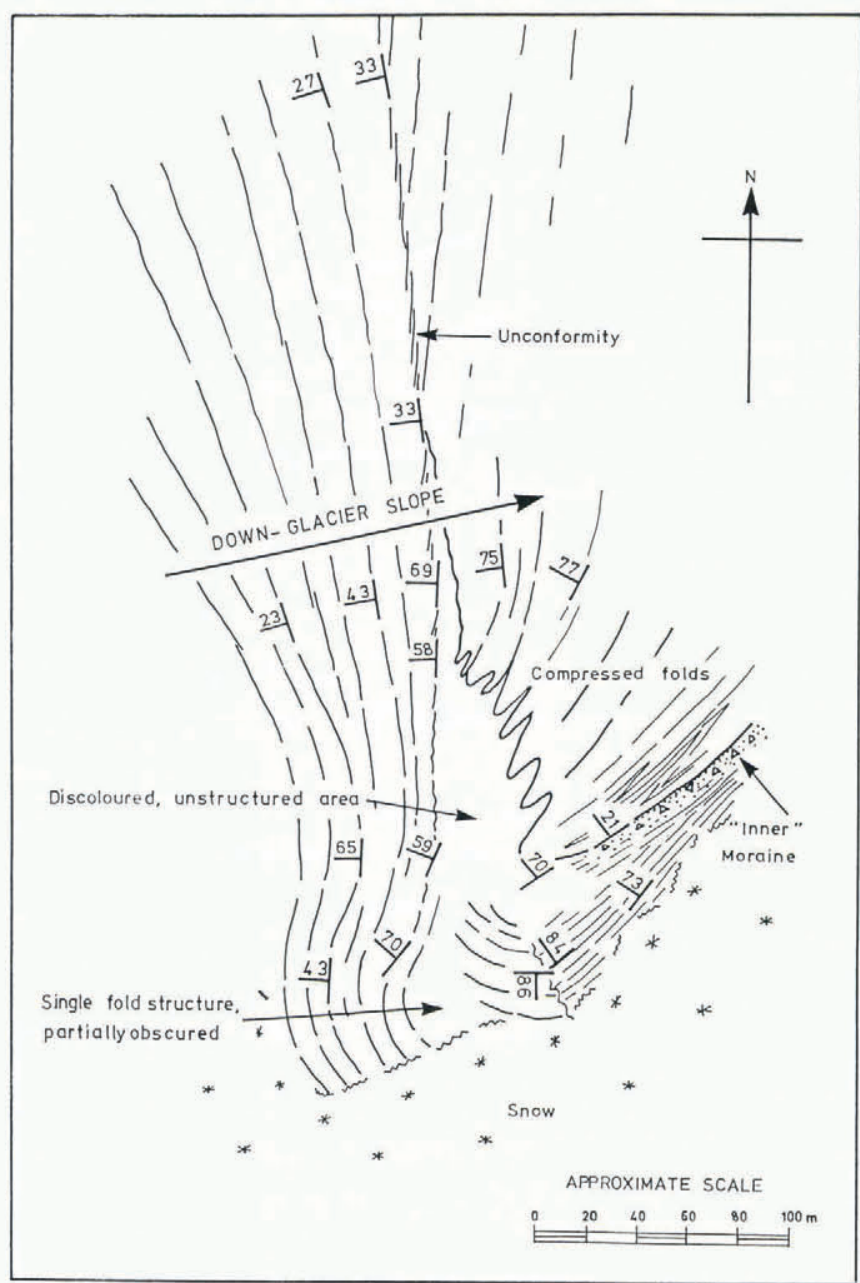

Fig. 9. Structural map of the complexly deformed area of Figure 6 on Jeremy Sykes Glacier.

(Hudleston, 1976). In Hudleston's model and that of Whillans and Jezek (1987), the fold is seeded by a décollement at or near an uneven glacier bed, and in the Hudleston model the fold is propagated by a change in the flow regime (either an advance or a retreat). The folds described here are unlikely to have been inherited from up-glacier bed irregularities, as the maximum distances from the fold to the névé headwall are only 0.5 and $1.0 \mathrm{~km}$, respectively, with no complications to the simple cirque structure. In this case, the folds have been initiated by an advance, in a position very much closer to the margins than in the Barnes Ice Cap study. The viscosity contrast for seeding may have been provided by the impurity content of the basal ice, and a viscosity contrast provided by the contrast between the zones of semi-rigid and semi-plastic ice which will have a significant influence on the behaviour of this shallow ice.
Ablation and movement measurements made across the inner moraine on the ramp margin of Alberich Glacier (Table I) indicate that uniform compressional flow continues from the glacier ice to the toe of the apron, with little indication that shearing and an abrupt velocity change occurs at the inner moraine as suggested by Bishop (1957), Souchez (1967), and Chinn and Dillon (1987). Here, the inner moraine indicates only the position where basal ice crops out at the surface, and does not mark the glacier boundary.

At a ramp margin in equilibrium where ice movement is balanced by ablation, the position of the inner moraine will remain fixed, while the debris supplied to the surface will be carried outward across the apron by the combined vectors of flow and ablation. A margin in equilibrium should therefore have an apron fully covered with a veneer of debris. At a receding ramp margin, the glacier will be thinning and the inner moraine position will migrate up-glacier. The apron will have a negative balance and will therefore carry a widespread debris cover. At an advancing margin, the position of the inner moraine will migrate outward, with some over-riding of the apron. A positive balance of the apron will conceal the bulk of the debris cover. The aprons of both Alberich and Jeremy Sykes Glaciers have only narrow bands of debris cover.

It is surmised that this type of fold occurs at a specific combination of velocity and ice depth, and that folds may conceivably form in both states of recession and advance, but it is considered that a fold is most likely to be initiated by a thickening wave of ice arriving at the glacier margin during an advance.

Although a fold may conceivably form when the glacier is at equilibrium, it is difficult to visualize the structure persisting in the forms seen during this study, as the lower limbs of the fold, below the inner moraine, must soon be lost to ablation. Should a fold form at a receding glacier margin, the fold centre would be expected to withdraw from the thinning ice and to migrate back towards the thicker ice of the glacier centre. This movement would be accompanied by a widespread debris cover over the thinning apron.

It is postulated that folds are most likely to form during an advance of these glaciers, where buckling occurs against thinner and stiffer marginal ice of the grounded part of the semi-rigid zone of Holdsworth (1969). Figure 10 demonstrates a suggested temporal sequence of events where a glacierette having a low-angled ramp front expands to become a glacier with a cliffed terminus. The relative positions of basal ice, inner moraine, and outer snow-and-ice apron are shown in the initial state in Figure 10(a). Growth during an advance initiates a fold (b), which grows until revealed at the surface by ablation (c) as the semi-circular structure. At this stage, both the original inner moraine and the new inner moraine at the fold core may occur simultaneously separated by a short distance. The original inner-moraine fragments were not seen during this study as the areas where they are predicted to occur were snow-covered. The fold is compressed with further thickening and expansion (d) and, as most of its bulk has been lost to ablation, it has no topographic expression on the glacier surface. Finally, all vestiges of the fold are

TABLE I. ICE MOVEMENT $\left(\mathrm{mm} \mathrm{a}^{-1}\right)$; SURFACE ABLATION (mm ICE $\mathrm{a}^{-1}$ ) Alberich Glacier

\begin{tabular}{|c|c|c|c|c|c|c|c|c|c|}
\hline Stake No. & 1B & $1 \mathrm{~A}$ & 1 & 2 & 3 & 4 & 5 & 6 & Mean* \\
\hline $\begin{array}{l}\text { Horizontal } \\
\text { movement }\end{array}$ & 10 & 20 & 30 & 50 & 110 & 110 & 190 & 190 & \\
\hline $\begin{array}{l}\text { Vertical } \\
\text { movement }\end{array}$ & 0 & 0 & +10 & +10 & +20 & +20 & +10 & +10 & \\
\hline Ablation & +41 & +10 & -40 & -4 & -76 & -36 & -46 & -34 & -35 \\
\hline Net surface- & +41 & +10 & -30 & +6 & -56 & -16 & -36 & -24 & \\
\hline
\end{tabular}




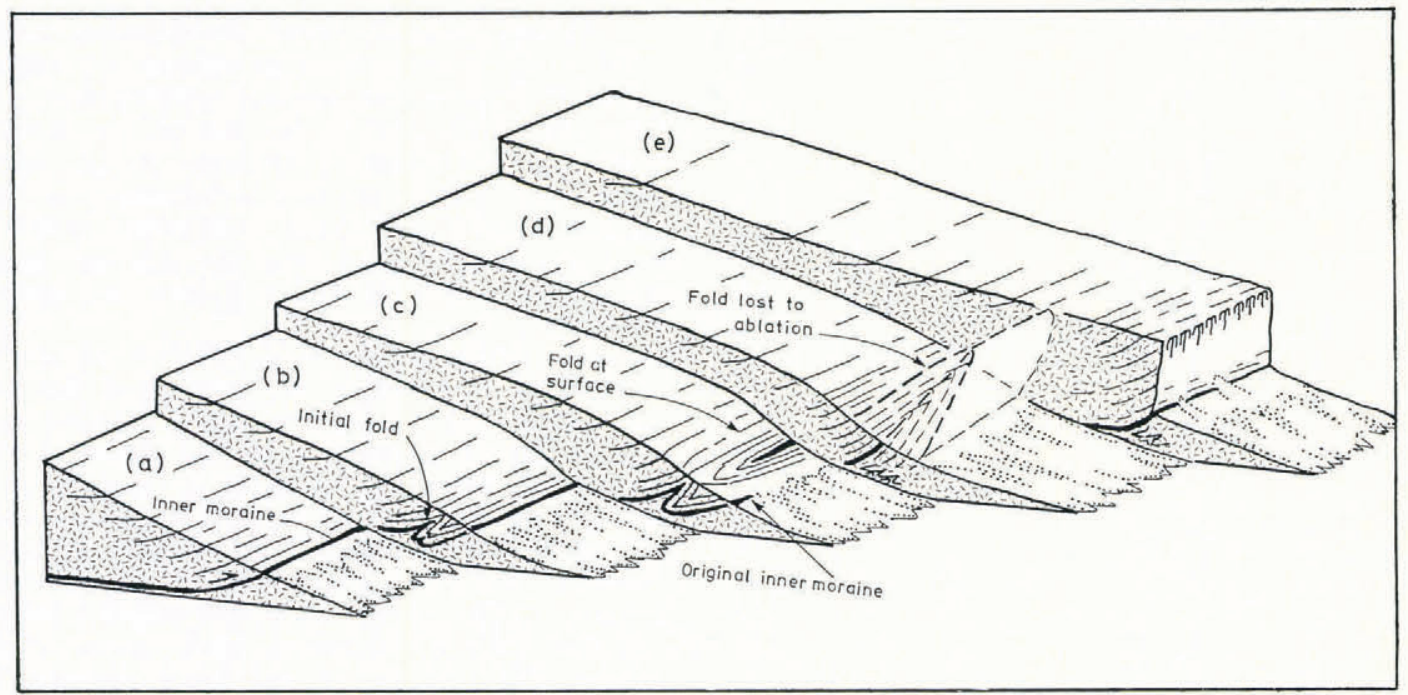

Fig. 10. Formation of a margin fold and subsequent evolution of a steepening margin form during an advance of a small, simple cirque glacier.

(a) Initial simple ramp-shaped margin with an inner moraine.

(b) Thickening of ice initiates a fold in the basal beds up-glacier of the inner moraine.

(c) The fold core exposed by ablation at a position inside the original moraine, revealing the semi-circular structures of this study.

(d) The fold is compressed and becomes recumbent, with most of its bulk lost to ablation.

(e) Climax form is a calving ice cliff where no vestiges of the fold remain.

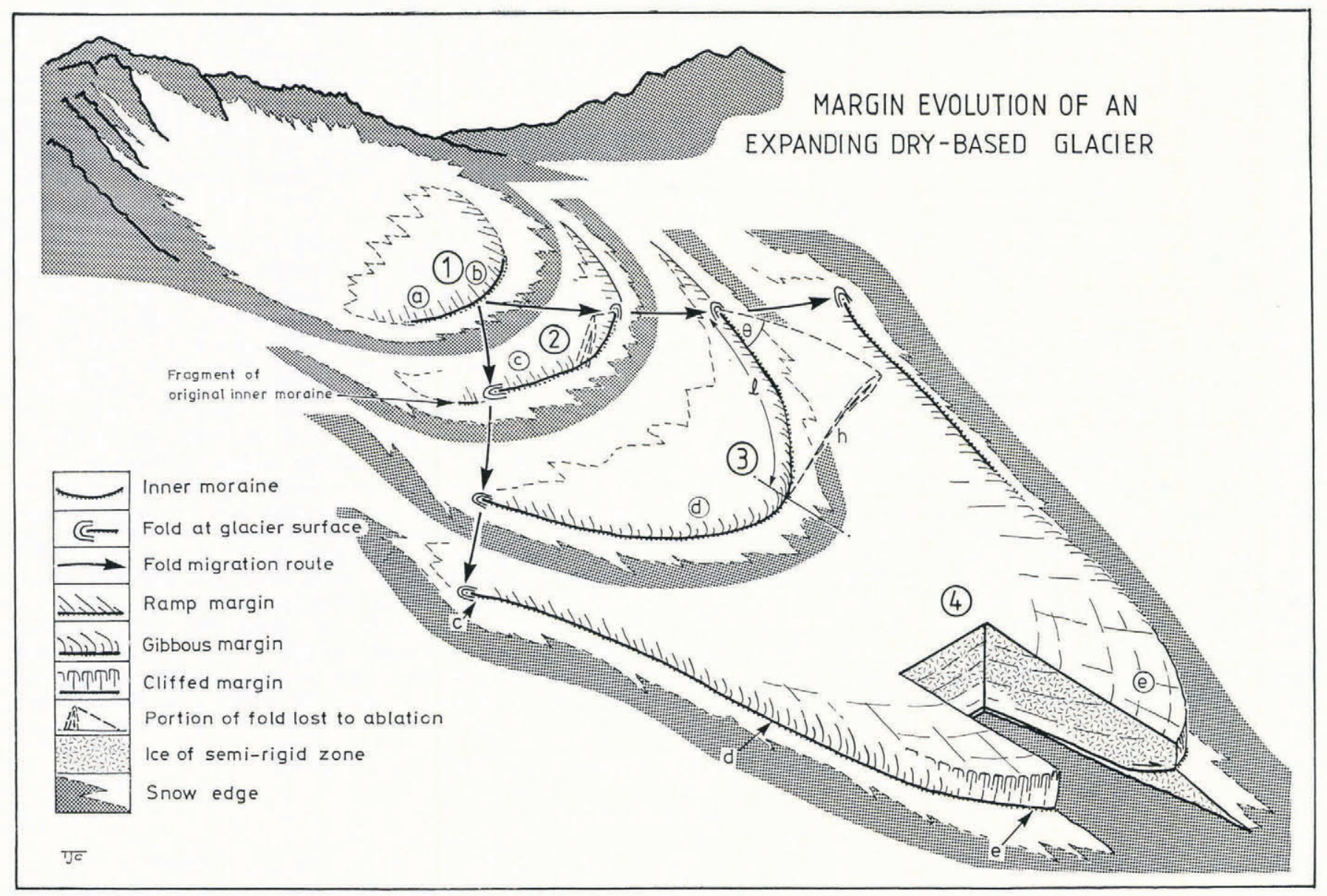

Fig. 11. Diagram showing margin evolution in four successive stages of an expanding dry-based cirque glacier. Margin forms (a)-(e) of Figure 10 are shown as they occur sequentially along the centre line of the expanding glacier, together with the spatially distributed positions of similar forms along the glacier margin of stage 4 .

Stage 1. (a) Ramped margin without folding; (b) Position where fold is initiated.

Stage 2. Folded margin (c).

Stage 3. Fold ends have migrated to the lateral margins and glacier centre has risen to a gibbous terminus (d); $h$, thickness of ice and original fold lost to ablation; $\ell$, length covered by migration of fold end; $\theta$, angle of plunge of fold.

Stage 4. Glacier expanded to form an ice-cliffed terminus. (c) Position of fold found on Alberich Glacier $c, d, e$, sequence of margin forms equivalent to the temporal forms (c), (d), (e) evolved during glacier expansion. 
obliterated by over-riding of the glacier front and ablation loss, and the glacier forms a cliffed margin (e).

Each of the forms of Figure 10, evolved at a glacier front during an advance, may co-exist spatially along the margin of a glacier. Alberich Glacier currently displays these forms around its southern margin (Fig. 4). This relationship between the margin forms developed at a glacier front over a period of time during an advance and those occurring simultaneously at the lateral margins is shown diagramatically in Figure 11.

The initial fold develops at (b) in Figure 11(1) in a manner similar to fold-nappe structures encountered in geological formations (Hobbs and others, 1976, p. 411) and, as the fold develops and moves forward, the fold ends are rolled outward to the lateral margins of the glacier (Fig. $11(2)$ ) in the direction of the arrows. As the advance proceeds, an increasing proportion of frontal ice containing the fold is lost to ablation as the glacier front evolves from the geological analogue of a fold nappe to a thrust nappe.

The amount of ice lost to ablation is represented by $h$ in Fig. 11(3), while the fold has migrated a distance $\ell$ from the glacier front. A value for $h$ may be estimated from the distance $\ell$ and $\theta$, the angle of plunge of the fold. With the development of a frontal ice cliff (Fig. 11(4)), the original fold may be still active at the upper lateral margins (c) with transitional marginal forms (d) and (e) leading downward to the glacier front.

The present dimensions of the fold, together with measured ablation rates, permit the age of the fold structures at their present location to be estimated. Assuming the fold amplitude is twice the fold width (the estimated maximum distance between beds involved in the fold, from stake 1 to stake 4 in Figure 7), the age of the exposed part of the fold may be estimated by calculating the time taken for the morainic core of the fold to be exposed by ablation.

For Jeremy Sykes Glacier:

Fold width $=100 \mathrm{~m}$;

Mean annual ablation rate $=75 \mathrm{~mm}($ Chinn, 1980);

$$
\text { Age }=\frac{\text { amplitude }}{\text { ablation }}=1300 \text { year }
$$

\section{For Alberich Glacier:}

Fold width $=50 \mathrm{~m}$;

Mean annual ablation rate $=35 \mathrm{~mm}$;

Age $=1400$ year

These values emphasize the low rate of activity of these glaciers.

If the initial fold is assumed to have formed at the centre of the glacier front, and to have rolled a distance $\ell$ (Fig. 11) around the margin as the advance proceeded, with fold plunge maintained at angles similar to those measured, then a time for the beginning of the advance may be crudely estimated. This estimation assumes that the angle of plunge, $\theta$, indicates the depth of fold $h$ lost to ablation where:

$$
h / \ell=\tan \theta .
$$

The time elapsed since the folds first formed, calculated by this method, gives 3500 year for Alberich Glacier and 18900 year for Jeremy Sykes Glacier. The latter value is an unacceptable length of time, and both values require unacceptably slow rates of ice movement in the order of $10^{-4} \mathrm{~m} \mathrm{a}^{-1}$. This indicates that the plunge of the folds has increased significantly during fold evolution.

\section{CONCLUSION}

This study of fold structures on Jeremy Sykes and Alberich Glaciers suggests that folds of this type are formed during an advance of the glacier. The folds form at the margins of small fully dry-based glaciers having low-angled fronts where ice flow is obstructed by stiff, grounded ice of the semi-rigid zone. This type of folding does not occur on temperate or polythermal glaciers having wet-based margins where basal slip relieves stress. The present morphology of Alberich Glacier suggests an evolutionary sequence in the growth of a small cirque glacier with a low-angled front to a glacier with a trunk and ice cliffs. An initial single fold forms first; this is overturned and bisected by the advancing ice of the glacier centre. During glacier expansion, the edges of the fold are rolled outward toward the lateral margins as the steepening front proceeds down-valley. The folds have an outward plunge and encircle the upper ends of the marginal inner moraine, and may persist on some fully developed trunked glaciers of the Dry Valleys area, where they appear as projecting "ears" between the cliffed glacier trunk and the nevé area. There is scope for further more detailed studies of these features.

\section{ACKNOWLEDGEMENTS}

The work reported here was sponsored by the New Zealand Ministry of Works and Development, with field support provided by the Antarctic Division, Department of Scientific and Industrial Research, and logistic support provided by the U.S. Navy. I am grateful for the assistance given in the field by R. Dickson and T. Butler, and for the helpful comments and review of the manuscript by $\mathrm{M}$. McSaveney.

\section{REFERENCES}

Bishop, B.C. 1957. Shear moraines in the Thule area, northwest Greenland. SIPRE Res. Rep. 17.

Bull, C. and C.R. Carnein. 1970. The mass balance of a cold glacier: Meserve Glacier, south Victoria Land, Antarctica. International Association of Scientific Hydrology Publication 86 (ISAGE), 429-446.

Chinn, T.J.H. 1980. Glacier balances in the Dry Valleys area, Victoria Land, Antarctica. International Association of Scientific Hydrology Publication 126 (Workshop at Riederalp - World Glacier Inventory), 237-247.

Chinn, T.J.H. 1981. Hydrology and climate in the Ross Sea area. J. R. Soc. N. Z., 11(4), 373-386.

Chinn, T.J.H. [1985.] Structure and equilibrium of the Dry Valleys glaciers. N.Z. Antarct. Rec., 6, Spec. Suppl., 73-88.

Chinn, T.J.H. 1987. Accelerated ablation at a glacier ice-cliff margin, Dry Valleys, Antarctica. Arc. Alp. Res., 19(1), 71-80.

Chinn, T.J.H. and A. Dillon. 1987. Observations on a debris-covered polar glacier "Whisky Glacier", James Ross Island, Antarctic Peninsula, Antarctica. J. Glaciol., 33(115), 300-310

Hobbs, B.E., W.D. Means, and P.F. Williams. '1976. An outline of structural geology. New York, John Wiley and Sons.

Holdsworth, G. 1969. Structural glaciology of Meserve Glacier. Antarct. J. U.S., 4(4), 126-128.

Holdsworth, G. Unpublished. Mode of flow of Meserve Glacier, Wright Valley, Antarctica. (Ph.D. thesis, Ohio State University, 1969.)

Hollin, J.T. and R.L. Cameron. 1961. I.G.Y. glaciological work at Wilkes Station, Antarctica. J. Glaciol., 3(29), 833-842.

Hooke, R.LeB. 1970. Morphology of the ice-sheet margin near Thule, Greenland. J. Glaciol., $9(57), 303-324$,

Hooke, R.LeB. 1973a. Flow near the margin of the Barnes Ice Cap and the development of ice-cored moraines. Geol. Soc. Am. Bull., 84(12), 3929-3948.

Hooke, R.LeB. 1973b. Structure and flow in the margin of the Barnes Ice Cap, Baffin Island, N.W.T., Canada. J. Glaciol., 12(66), 423-438.

Hudleston, P.J. 1976. Recumbent folding in the base of the Barnes Ice Cap, Baffin Island, Northwest Territories, Canada. Geol. Soc. Am. Bull., 87(12), 1684-1692.

Johnson, A.M. 1977. Styles of folding, mechanics and mechanisms of folding of natural elastic materials. Dev. Geotectonics, 11. 
McSaveney, M.J. 1974. A 3.1-meter recession of Meserve Glacier, Wright Valley. Antarct. J. U.S., 9(4), 166-167.

Souchez, R.A. 1967. The formation of shear moraines: an example from south Victoria Land, Antarctica. J. Glaciol., 6(48), 837-843.

Souchez, R.A. 1971. Ice-cored moraines in south-western Ellesmere Island, N.W.T., Canada. J. Glaciol., 10(59), 245-254.
Thompson, D.C. 1973. Climate of the Dry Valleys area of southern Victoria Land. N.Z. Geogr. Soc. Conf. Ser. 7, 259-265.

Weertman, J. 1961. Mechanisms for the formation of inner moraines found near the edge of cold ice caps and ice sheets. J. Glaciol., 3(30), 965-978.

Whillans, I.M. and K.C. Jezek. 1987. Folding in the Greenland ice sheet. J. Geophys. Res., 92(B1), 485-493. 